\title{
PENERAPAN MODEL PJBL BERBANTUAN MEDIA AUDIOVISUAL UNTUK MENINGKATKAN HASIL BELAJAR IPA
}

\author{
I Gusti Ayu Jayanti Kusuma ${ }^{1}$, I Gusti Ngurah Japa \\ 1,2 Jurusan Pendidikan Guru Sekolah Dasar, FIP \\ Universitas Pendidikan Ganesha \\ Singaraja, Indonesia \\ email : igustiayujayantikusuma@gmail.com ${ }^{1}$, ngriapa pgsd@yahoo.co.id ${ }^{2}$
}

\begin{abstract}
Abstrak
Penelitian ini bertujuan untuk mengetahui hasil belajar IPA di SD Negeri 3 Banjar Jawa Singaraja Tahun Pelajaran 2017/2018 setelah penerapan model pembelajaran berbasis proyek berbantuan media audiovisual. Jenis penelitian ini adalah penelitian tindakan kelas yang dilaksanakan dalam dua siklus. Subyek penelitian adalah siswa VA SD Negeri 3 Banjar Jawa, sebanyak 32 orang. Bentuk analisis data yang digunakan adalah statistik deskriptif dan analisis deskriptif kuantitatif. Hasil penelitian menunjukkan bahwa pada refleksi awal rata-rata hasil belajar IPA hanya mencapai 76 dengan (M\%) sebesar 76\% yang masih berada pada kategori sedang. Hasil penelitian meningkat pada siklus I dengan rata-rata nilai 76 dan (M\%) sebesar $79 \%$ yang juga masih berada pada kategori sedang. Setelah dilaksanakan perbaikan tindakan pada siklus II, rata-rata nilai hasil belajar IPA siswa semakin meningkat mencapai 86 dengan (M\%) sebesar $86 \%$ yang sudah masuk pada kategori tinggi. Adapun peningkatan hasil belajar IPA dapat dilihat dari hasil perhitungan gain score (Gn) adalah sebesar 0,42. Dengan demikian model pembelajaran berbasis proyek berbantuan media audiovisual dapat meningkatkan hasil belajar IPA siswa kelas VA di SD Negeri 3 Banjar Jawa Singaraja Tahun Pelajaran 2017/2018.
\end{abstract}

Kata kunci: hasil belajar IPA, media audiovisual, model pembelajaran berbasis proyek

\begin{abstract}
The purpose of this study is to improve result in learning science through project based learning model application assisted by audiovisual media on VA grade students of SDN 3 Banjar Jawa Singaraja in academic year 2017/2018. This study used classroom action research which conducted in two cycles. Each cycle consists of four phases: planning, implementation, observation, and reflection. The subject were VA grade students in SDN 3 Banjar Jawa Singaraja in academic year 2017/2018 that included 32 students. The result of learning science's datas is analyzed using quantitative descriptive analysis and qualitative descriptive analysis. The result showed that at the early reflection, average of result in learning science was only 76 with $(\mathrm{M} \%)=$ $76 \%$. It was still in middle category. The result of the study increased in $1^{\text {st }}$ cycle with average 79 and $(\mathrm{M} \%)=79$. It is also still in middle category. After the improvement of action on $2^{\text {nd }}$ cycle. Student's average value reachs 86 with $(\mathrm{M} \%)=86 \%$. It means that there was enhancement of gain score in the amount of 0,42. Based on the results can be concluded that application of project based learning model assisted by audiovisual media can improve result in learning science of VA grade students in SD Negeri 3 Banjar Jawa SIngaraja, academic year 2017/2018.
\end{abstract}

Keywords: audiovisual media, project based learning, result in learning science 


\section{Pendahuluan}

Keberhasilan proses pembelajaran sebagai proses pendidikan di sekolah dipengaruhi oleh banyak faktor. Faktor-faktor tersebut seperti guru, peserta dipik, kurikulum, dan lingkungan sosial. Dari faktor-faktor tersebut, guru dan siswa merupakan faktor yang terpenting. Peran guru menjadi penting dalam proses pembelajaran karena dari seorang gurulah siswa itu belajar. Guru mengarahkan dan menjadi fasilitator bagi siswanya agar dapat memperoleh pengalaman belajar dalam rangka meningkatkan hasil belajar baik dari kompetensi pengetahuan, keterampilan, maupun sikap sebagai bekal di masa depan siswa kelak.

Sekolah dasar merupakan titik awal pendidikan formal yang menyediakan guru sebagai fasilitator dari proses pendidikan itu. Sekolah dasar memiliki peran besar sebagai pondasi pengetahuan bagi siswa untuk dapat melanjutkan pendidikan ke tingkatan selanjutnya. Di sekolah dasar inilah siswa akan dididik beberapa cara untuk mengubah perilakunya dari tidak bisa menjadi bisa, dari tidak tahu menjadi tahu, dan menjadikan siswa memiliki penguasaan keterampilan serta sikap yang baik. Untuk mewujudkan pendidikan tersebut disusunlah suatu kurikulum. Kurikulum yang diterapkan saat ini adalah kurikulum 2013. Kurikulum ini lebih menekankan pada kompetensi dengan pemikiran kompetensi berbasis sikap, keterampilan, dan pengetahuan (Depdikbud, 2014). Kurikulum 2013 memiliki tujuan untuk meningkatkan rasa ingin tahu siswa dan mendorong siswa untuk aktif sehingga siswa bukan lagi menjadi objek tapi justru menjadi subjek dalam belajar.

Kurikulum sebagai pengatur kegiatan pembelajaran yang terjadi di dalam kelas, dengan kata lain kegiatan pembelajaran yang terjadi di kelas sangat dipengaruhi oleh kurikulum yang berlaku. Pembelajaran ialah membelajarkan siswa menggunakan asas pendidikan maupun teori belajar yang merupakan penentu utama keberhasilan pendidikan. Pembelajaran merupakan proses komunikasi dua arah, mengajar dilakukan oleh pihak guru sebagai pendidik, sedangkan belajar dilakukan oleh siswa atau siswa. Secara umum, proses pembelajaran dalam Kurikulum 2013 dimulai dari kompetensi pengetahuan (KI-3) dan kompetensi keterampilan (KI4), sedangkan kompetensi sikap spiritual (KI-1) dan kompetensi sikap sosial (KI-2) merupakan dampak yang diharapkan muncul dari proses pembelajaran (Sani, 2014:49). Keempat kompetensi ini kemudian dimunculkan dalam setiap proses pembelajaran.

Ada lima mata pelajaran dasar dalam proses pembelajaran pada tingkat sekolah dasar yang salah satunya adalah IPA. IPA merupakan salah satu mata pelajaran yang menjadi mata pelajaran pokok dalam kurikulum 2013 dan dimulai dari jenjang sekolah dasar. Dalam penerapan pembelajaran kurikulum 2013 mata pelajaran menjadi tematik integratif, yaitu mata pelajaran dengan menggunakan tema yang menghubungkan berbagai mata pelajaran. Pengetahuan IPA yang dipelajarari di sekolah dasar tergabung dengan mata pelajaran lain dalam sebuah tema.

Dahulu, saat ini, dan saat yang akan datang IPA atau IImu Pengetahuan Alam memegang peranan sangat penting dalam kehidupan manusia. Hal ini disebabkan karena kehidupan kita sangat tergantung dari alam, zat terkandung di alam, dan segala jenis gejala yang terjadi di alam (Wisudawati dan Sulistyowati (2014:22-24). Didefinisikan pula bahwa IPA memiliki empat unsur, yaitu: sikap, proses, produk, dan aplikasi. Dalam proses pembelajaran IPA keempat unsur itu diharapkan dapat muncul sehingga siswa dapat mengalami proses pembelajaran secara utuh dan menggunakan rasa ingin tahunya untuk memahami fenomena alam melalui kegiatan pemecahan masalah yang menerapkan langkah-langkah metode ilmiah. Metode ilmiah ini identik dengan penggunaan pendekatan saintifik.

Menurut Daryanto (2014:55), pendekatan saintifik (scientific) disebut juga sebagai pendekatan ilmiah. Proses pembelajaran dapat dipadankan dengan suatu proses ilmiah. Karena itu Kurikulum 2013 mengamanatkan esensi pendekatan saintifik dalam pembelajaran. Pendekatan saintifik diyakini berdampak positif bagi perkembangan dan pengembangan sikap, keterampilan, dan pengetahuan siswa. Melalui penggunaan pendekatan saintifik ini akan melahirkan penemuan-penemuan baru yang akan menjadi produk sains.

Pada kenyataannya implementasi kurikulum 2013 dalam pembelajaran masih belum seperti apa yang diharapkan. Dari observasi yang dilakukan di SD Negeri 3 Banjar Jawa 
Singaraja ditemukan beberapa masalah, antara lain: (1) masih kurang variatifnya media pembelajaran yang digunakan dalam proses pembelajaran, (2) tingkat gradasi keterampilan siswa masih belum diarahkan hingga mencipta padahal akan sangat baik jika pengetahuan yang didapat kemudian dapat diaplikasikan menjadi sebuah produk nyata, (3) beberapa siswa kurang disiplin saat belajar, (4) diskusi kelompok masih didominasi oleh siswa yang pintar. Beberapa masalah ini pun menyebabkan rendahnya hasil belajar siswa terutama pada muatan materi IPA. Hal ini dapat dilihat dari rendahnya rerata dan persentase rata-rata nilai siswa pada muatan materi IPA. Untuk nilai rata-rata yaitu sebesar 76 yang masih masuk pada kategori sedang pada skala PAP dengan rerata presentase nilai siswa (M\%) sebesar 76\%.

Perbaikan pembelajaran pun kemudian direncanakan untuk dilaksanakan di SD Negeri 3 Banjar Jawa Singaraja khususnya pada muatan materi IPA sebagai upaya meningkatkan hasil belajar siswa yang dibarengi peningkatan kualitas pembelajaran.

Melihat kenyataan tersebut di atas, maka dirasa perlu untuk menerapkan model maupun media pembelajaran dalam pengaplikasian kurikulum 2013 dengan pendekatan saintifik dalam kegiatan pembelajaran. Pembelajaran dengan pendekatan saintifik merupakan proses pembelajaran yang dirancang sedemikian rupa agar siswa secara aktif mengonstruk konsep, hukum atau prinsip melalui tahapan-tahapan mengamati (untuk mengidentifikasi atau merumuskan masalah), merumuskan masalah, mengajukan atau merumuskan hipotesis, mengumpulkan data dengan berbagai teknik, menganalisis data, menarik kesimpulan dan mengkomunikasikan konsep, hukum atau prinsip yang ditemukan.

Salah satu usaha yang dapat dilakukan untuk mengatasi hal tersebut adalah penerapan model pembelajaran berbasis proyek (PjBL) berbantuan media audiovisual. Pembelajaran berbasis proyek memang merupakan salah satu model pembelajaran yang kerap digunakan dalam pendekatan saintifik pada Kurikulum 2013 ini. Pembelajaran berbasis proyek ini menggunakan proyek atau kegiatan sebagai tujuannya. Pembelajaran berbasis proyek juga memfokuskan pada aktivitas siswa yang berupa pengumpulan informasi dan pemanfaatannya untuk menghasilkan sesuatu yang bermanfaat bagi kehidupan siswa itu sendiri ataupun bagi orang lain, namun tetap terkait dengan kompetensi dasar (KD) dalam kurikulum (Kosasih, 2014:96).

Istilah pembelajaran berbasis proyek merupakan istilah pembelajaran yang diterjemahkan dari istilah dalam bahasa Inggris pembelajaran berbasis proyek. Menurut Buck Institute for Education (dalam Al-Tabany, 2014:41) bahwa pembelajaran berbasis proyek adalah model pembelajaran yang melibatkan siswa dalam kegiatan pemecahan masalah dan memberi peluang siswa bekerja secara otonom mengkonstruksi belajar mereka sendiri, dan puncaknya menghasilkan produk karya siswa bernilai dan realistik.

Pembelajaran berbasis proyek dapat didefinisikan sebagai sebuah pembelajaran dengan aktivitas jangka panjang yang melibatkan siswa dalam merancang, membuat, dan menampilkan produk untuk mengatasi permasalahan dunia nyata. Ciri khas dari pembelajaran berbasis proyek yang membedakannya dengan model pembelajaran lainnya adalah adanya produk yang harus dibuat dan ditampilkan oleh siswa dalam pembelajaran berbasis proyek.

Pembelajaran berbasis proyek merupakan model pembelajaran yang melibatkan siswa untuk mengerjakan sebuah proyek yang bermanfaat untuk menyelesaikan permasalahan yang dihadapi dalam pembalajaran, masyarakat atau lingkungan. Proyek yang dibuat dapat berupa proyek dari satu guru, atau proyek bersama dari beberapa guru yang mengasuh pelajaran yang berbeda. Siswa dilatih untuk melakukan analisis terhadap permasalahan, kemudian melakukan eksplorasi, mengumpulkan informasi, interpretasi, dan penilaian dalam mengerjakan proyek yang terkait dengan permasalahan yang dikaji. Pembelajaran ini memungkinkan siswa untuk mengembangkan kreativitasnya dalam merancang dan membuat proyek yang dapat dimanfaatkan untuk mengatasi permasalahan. Pembelajaran berbasis proyek didasarkan pada teori konstruktivisme dan merupakan pembelajaran siswa aktif (student centered learning). Proses pembelajaran melalui pembelajaran berbasis proyek memungkinkan guru untuk "belajar dari siswa" dan "belajar bersama siswa". Pembelajaran melalui pembelajaran berbasis proyek juga dapat digunakan sebagai metode belajar untuk mengembangkan kemampuan 
siswa dalam membuat perencanaan, berkomunikasi, menyelesaikan masalah, dan membuat keputusan.

Menurut Sani (2014:174), pembelajaran berbasis proyek dilakukan untuk memperdalam pengetahuan dan keterampilan yang diperoleh dengan cara membuat karya atau proyek yang terkait dengan materi ajar dan kompetensi yang diharapkan dimiliki oleh siswa. Proyek bisa dibuat berupa prototipe atau produk sederhana, misalnya: tulisan untuk majalah sekolah, majalah dinding tentang permasalahan lingkungan, buku mini, kliping, pompa air sederhana, membuat kebun, pupuk organik dari lingkungan sekitar, daur ulang sampah, dan sebagainya.

Model pembelajaran berbasis proyek mencakup kegiatan menyelesaikan masalah (problem solving), pengambilan keputusan, keterampilan melakukan investigasi, dan keterampilan membuat karya. Siswa harus fokus pada penyelesaian masalah atau pertanyaan yang memandu mereka untuk memahami konsep dan prinsip yang terkait dengan proyek. Masing-masing kelompok belajar mungkin mengajukan proyek yang berbeda untuk menyelesaikan masalah yang ditemui. Guru berperan dalam membantu siswa merencanakan pengerjaan proyek, menganalisis sketsa atau rancangan proyek jika diminta oleh kelompok, mengurus kebutuhan kerja sama yang mungkin diperlukan. Pemahaman siswa secara mendalam tentang konsep dan prinsip merupakan sasaran yang dikehendaki dalam.melibatkan mereka dalam mengerjalan sebuah proyek.

Susanto (2013:208) berpendapat, "pemerolehan pengetahuan dan proses pemahaman akan sangat terbantu, apabila siswa dapat sekaligus melakukan sesuatu yang terkait dengan keduanya, yaitu dengan mengerjakannya maka siswa akan menjadi lebih tahu dan paham". Dalam hal ini model pembelajaran berbasis proyek sangat sesuai karena inti dari model pembelajaran ini adalah siswa "mengerjakan" apa yang dipelajarinya sehingga dapat meningkatkan hasil belajar kompetensi pengetahuan, kompetensi keterampilan, maupun kompetensi sikap.

Menurut Moursund (dalam Wena, 2014:147) ada beberapa keuntungan pembelajaran berbasis proyek, yaitu : (1) Increased motivation, yaitu siswa menjadi sangat tekun, sangat bergairah dalam belajar, dan keterlambatan dalam kehadiran sangat berkurang; (2) Increased problem solving ability atau meningkatnya kemampuan memecahkan masalah, membuat siswa lebih aktif dan berhasil memecahkan problem-problem yang bersifat kompleks; (3) Improved library research skill, karena pembelajaran berbasis proyek mempersyaratkan siswa harus mampu secara cepat memperoleh informasi melalui sumber-sumber informasi, maka keterampilan siswa untuk mencari dan mendapatkan informasi akan meningkat; (4) Increased colaboration, yaitu pentingnya kerja kelompok dalam proyek yang membuat siswa mengembangkan dan mempraktikkan keterampilan komunikasi. Kelompok kerja kooperatif, evaluasi siswa, pertukaran informasi online adalah aspek-aspek kolaboratif dari sebuah proyek; dan (5) increased resource-management skills, yaitu pembelajaran berbasis proyek yang diimplementasikan secara baik memberikan kepada siswa pembelajaran dan praktik dalam mengorganisasi proyek, dan membuat alokasi waktu dan sumber-sumber lain seperti perlengkapan untuk menyelesaikan tugas.

Pembelajaran berbasis proyek juga didukung oleh teori belajar konstruktivistik dan dipandang sebagai salah satu penciptaan lingkungan belajar yang dapat mendorong siswa mengkonstruk pengetahuan dan keterampilannya secara personal. Ketika pembelajaran berbasis proyek dilakukan dalam model belajar kolaboratif dalam kelompok kecil siswa, Vygotsky memberikan landasan pengembangan pengetahuan (kognitif) melalui peningkatan intensitas interaksi atarpesonal. Proses interaktif antar teman sejawat membantu proses konstruksi pengetahuan. Dari perspektif teori ini pembelajaran berbasis proyek dapat membantu siswa meningkatkan keterampilan memecahkan masalah secara kolaboratif yang dapat mengembangkan sikap kerja sama (Wena, 2014:148).

Agar lebih efektif, model pembelajaran berbasis proyek ini dapat diintegrasikan dengan media pembelajaran yang menarik. Arsyad (2014) menyimpulkan beberapa manfaat praktis dari media pembelajaran, yaitu media pembelajaran dapat memperjelas penyajian pesan dan informasi sehingga dapat meningkatkan proses dan hasil belajar, menimbulkan motivasi belajar, interaksi antara siswa dan lingkungannya, memungkinkan siswa belajar sesuai dengan 
minat dan kemampuannya. Selain itu media juga dapat mengatasi keterbatasan indera, ruang, dan waktu karena objek atau benda yang terlalu besar, memiliki proses yang amat rumit, atau percobaan yang dapat membahayakan untuk ditampilkan langsung di ruang kelas dapat diganti dengan gambar, foto, slide, realita, film, radio, atau model. Dalam pembelajaran berbasis proyek ini, salah satu media yang dapat digunakan adalah media audiovisual.

Media audiovisual merupakan bentuk media pembelajaran yang murah dan terjangkau. Materi audio dapat digunakan dan disesuaikan dengan tingkat kemampuan siswa. Audio dapat menampilkan pesan yang memotivasi. Audio (suara) ini dapat dikombinasikan dengan slide (visual) sehingga menjadi media audiovisual. Arsyad (2014:146) menyatakan gabungan slide (film bingkai) dengan tape audio adalah jenis sistem multimedia yang paling mudah diproduksi. Sistem multimedia ini serba guna, mudah digunakan, dan cukup efektif untuk pembelajaran kelompok atau pembelajaran perorangan dan belajar mandiri. Jika didesain dengan baik, sistem multimedia gabungan slide (visual) dan tape (audio) dapat membawa dampak yang dramatis dan tentu saja dapat meningkatkan hasil belajar.

Hasil belajar dalam penelitia ini pun dijelaskan menurut Dimyati dan Mudjiono (2009:3) hasil belajar merupakan hal yang dapat dipandang dari dua sisi yaitu sisi guru dan siswa. Dari sisi siswa, hasil belajar merupakan tingkat perkembangan mental yang lebih baik bila dibandingkan pada saat sebelum belajar. Tingkat perkembangan mental tersebut terwujud pada jenis-jenis aspek sikap, pengetahuan, dan keterampilan. Sedangkan dari sisi guru hasil belajar merupakan saat terselesaikannya bahan pelajaran.

Dalam kegiatan pembelajaran atau kegiatan instruksional, biasanya guru menetapkan tujuan belajar untuk mengetahui seberapa besar keberhasilan siswa telah menguasai kompetensi atau materi yang telah diajarkan. Untuk mengetahui keberhasilan siswa dilakukan evaluasi atau penilaian hasil belajar yang merupakan tindak lanjut atau cara untuk mengukur tingkat penguasaan kompetensi oleh siswa (Jihad dan Haris, 2014:15).

Menyadari adanya kondisi tersebut pada siswa, guru dan proses pembelajaran IPA di kelas VA SD Negeri 3 Banjar Jawa Singaraja, maka melalui Penelitian Tindakan Kelas (PTK) ini akan dicoba untuk menerapkan model pembelajaran berbasis proyek berbantuan media audiovisual pada siswa kelas VA SD Negeri 3 Banjar Jawa Singaraja dengan harapan dapat meningkatkan hasil belajar IPA siswa. Atas dasar ini, maka akan diadakan penelitian dengan judul "Penerapan Model Pembelajaran Berbasis Proyek Berbantuan Media Audiovisual Untuk Meningkatkan Hasil Belajar IPA Siswa Kelas VA di SD Negeri 3 Banjar Jawa Singaraja".

Adapun tujuan penelitian ini adalah Untuk meningkatkan hasil belajar IPA siswa kelas VA melalui penerapan model pembelajaran berbasis proyek berbatuan media audiovisual di SD Negeri 3 Banjar Jawa Singaraja tahun ajaran 2017/2018.

\section{Metode}


Penelitian ini dilaksanakan di kelas VA semester II tahun pelajaran 2017/2018 SD Negeri 3 Banjar Jawa Singaraja pada muatan materi IPA. Subjek dalam penelitian ini adalah adalah siswa kelas siswa kelas VA SD Negeri 3 Banjar Jawa Singaraja tahun ajaran 2017/2018 yang berjumlah 32 orang siswa.

Adapun model yang dipilih dalam penelitian ini adalah model PTK yang dirancang dalam siklus yang mengikuti model Kurt Lewin. Model Kurt Lewin Merupakan model pertama dalam PTK yang diperkenalkan pada tahun 1946 dan merupakan acuan pokok atau dasar dari berbagai model PTK yang lain (Taniredja, 2011:23). Kurt Lewin menjelaskan bahwa ada empat hal yang harus dilakukan dalam proses penelitian tindakan yakni perencanaan, tindakan, observasi dan refleksi. Pelaksanaan penelitian tindakan adalah proses yang terjadi dalam suatu lingkaran yang terus menerus (Sanjaya, 2013:154).

Pada penelitian ini, data yang digunakan adalah data tentang kompetensi pengetahuan yang dikumpulkan dengan metode tes. Metode tes digunakan pada setiap akhir siklus dengan menggunakan tes untuk mengetahui peningkatan hasil belajar kompetensi pengetahuan IPA siswa melalui penerapan model pembelajaran berbasis proyek berbantuan media audiovisual. Metode tes adalah cara memperoleh data yang berbentuk suatu tugas yang harus dikerjakan oleh seseorang atau kelompok orang yang di tes (testee), dan dari tes dapat menghasilkan suatu skor. Menurut Sudjana (2013:35), "tes sebagai alat penilaian adalah pertanyaan-pertanyaan yang diberikan kepada siswa untuk mendapat jawaban dari siswa dalam bentuk lisan (tes lisan), dalam bentuk tulisan (tes tulisan), atau dalam bentuk perbuatan (tes tindakan)".

Dalam penelitian ini, tes yang digunakan yakni tes objektif pilihan ganda. Tes objektif pilihan ganda (multiple choice test) terdiri atas suatu keterangan atau pemberitahuan tentang suatu pengertian yang belum lengkap dan utnuk melengkapinya harus memilih satu dari beberapa kemungkinan jawaban yang telah disediakan (Arikunto, 2013:183). Kunci jawaban memberikan informasi apakah jawaban siswa benar atau salah. Oleh karena itu melalui tes objektif ini peneliti berharap memperoleh data mengenai hasil belajar pengetahuan IPA siswa kelas VA SD Negeri 3 Banjar Jawa Singaraja.

Instrumen pengumpulan data adalah alat atau fasilitas yang digunakan oleh peneliti dalam mengumpulkan data agar pekerjaannya lebih mudah dan hasilnya lebih baik, dalam arti lebih cermat, lengkap dan sistematis, sehingga lebih mudah diolah. Instrumen penelitian yang digunakan dalam penelitian ini adalah tes objektif pilihan ganda biasa sebanyak 20 butir soal yang sudah divalidasi secara teoritik meliputi validias isi yang dikonsultasikan dengan dosen pembimbing, guru pamong, dan guru kelas tempat pelaksanaan PTK.

\section{Hasil Dan Pembahasan}

Penelitian tindakan kelas dengan menerapkan model pembelajaran berbasis proyek berbantuan media audiovisual pada pembelajaran dengan muatan materi IPA dilaksanakan dalam dua siklus tindakan, yang tiap siklus terdiri dari 3 kali pertemuan untuk pelaksanaan tindakan dan 1 kali evaluasi. Pelaksanaan pembelajaran dengan menggunakan model pembelajaran berbasis proyek berbantuan media audiovisual secara umum telah berlangsung sesuai dengan rencana pelaksanaan pembelajaran yang dibuat secara kolaboratif antara peneliti bersama dan guru kelas yang dikonsultasikan dengan dosen pembimbing. Dalam pembelajaran guru memberikan permasalahan-permasalahan yang berhubungan dengan kehidupan nyata yang dibawa ke kelas dengan menggunakan bantuan media audiovisual berupa video pembelajaran. Permasalahan tersebut dicari pemecahannya oleh siswa secara berkelompok. Siswa lalu mengumpulkan informasi, menanya, dan mengasosiasi informasi tersebut ke dalam bentuk proyek yang ditugaskan oleh guru. Dengan dibuatnya proyek dalam memecahkan masalah, berarti juga siswa sudah mengaplikasikan ilmu pengetahuan yang diperoleh menjadi bentuk nyata yang bermanfaat bagi siswa maupun orang lain dalam kehidupan sehari-hari. Dalam pembelajaran siklus I, guru mengelompokkan siswa menjadi 6 kelompok secara heterogen yang masing masing 
terdiri dari 5-6 siswa. Setiap kelompok ditugaskan untuk berdiskusi dalam mengumpulkan informasi dari hasil pengamatan video, teks bacaan pada buku, penjelasan guru, dari internet, maupun bertanya pada orang tua di rumah. informasi tersebut kemudian permasalahan yang diberikan ataupun bekerjasama dalam melakukan percobaan.

Pada siklus I diterapkan model pembelajaran berbasis proyek berbantuan media audiovisual dengan membawa masalah yang ada di dunia nyata ke dalam bentuk video agar lebih mudah diamati oleh siswa. Permasalahan tersebut kemudian dipecahkan dengan mengumpulkan informasi secara berkelompok dari berbagai sumber yang kemudian diasosiasi oleh siswa dengan bimbingan guru untuk dicarikan solusinya. Solusi yang ditawarkan dalam model pembelajaran berbasis proyek ini yaitu, hasil pengamatan dan pengumpulan informasi langsung diolah (diasosiasi) menjadi sebuah bentuk produk hasil proyek atau sebuah karya yang nyata sebagai bagian dari pengaplikasian ilmu pengetahuan yang didapatkan oleh siswa. Setelah diterapkan model pembelajaran berbasis proyek berbantuan media audiovisual dalam pelaksanaan tindakan pada siklus I dengan tiga kali pertemuan untuk pelaksanaan tindakan dan satu kali untuk evaluasi didapatkan peningkatan rata rata nilai siswa yang dapat dilihat pada diagram berikut:

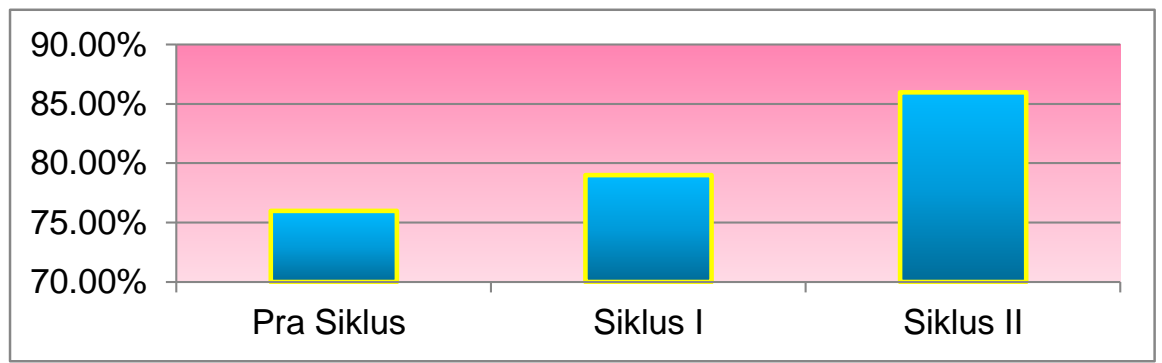

Gambar 1. Peningkatan Persentase Indikator Pencapaian Hasil Belajar pada Kompetensi Pengetahuan IPA pada Pra Siklus, Siklus I dan Siklus II 
Tabel 1. Tabel Rekapitulasi Indikator Pencapaian Data Hasil Belajar IPA pada Kompetensi Pengetahuan IPA Siswa Kelas VA SDN 3 Banjar Jawa Singaraja Pra Siklus, Siklus I, dan Siklus II

\begin{tabular}{lccccc}
\hline & Data & Pra Siklus & Siklus I & Siklus II & Gain Score (Gn) \\
\hline $\begin{array}{l}\text { Indikator } \\
\text { belajar } \begin{array}{c}\text { pencapaian hasil } \\
\text { pada kompetensi }\end{array}\end{array}$ & $76 \%$ & $79 \%$ & $86 \%$ & 0,42 \\
pengetahuan IPA
\end{tabular}

Berdasarkan grafik dan tabel diatas dapat dilihat ada peningkatan nilai siswa dari pra siklus ke siklus I yaitu 76 menjadi 79 dengan persentase rerata nilai siswa (M\%) dari $76 \%$ menjadi $79 \%$. Walaupun terjadi peningkatan hasil belajar pada kompetensi pengetahuan IPA namun belum mencapai indikator keberhasilan yang ditetapkan dalam penelitian ini, sehingga penelitian ini dilanjutkan ke siklus II dengan perbaikan berdasarkan permasalahan yang ditemukan pada siklus I.

Setelah perbaikan-perbaikan tersebut dilaksanakan pada siklus II, didapatkan hasil belajar pada kompetensi pengetahuan IPA siswa meningkat dari siklus I dengan indikator keberhasilan rata-rata nilai siswa mencapai 86 dengan kategori tinggi dan persentase rerata nilai (M\%) sebesar $86 \%$.

Pembelajaran berbasis proyek memfokuskan pada aktivitas siswa yang berupa pengumpulan informasi dan pemanfaatannya untuk menghasilkan sesuatu yang bermanfaat bagi kehidupan siswa itu sendiri ataupun bagi orang lain, namun tetap terkait dengan kompetensi dasar (KD) dalam kurikulum (Kosasih, 2014:96). Dengan diterapkannya pembelajaran berbasis proyek berbantuan media audiovisual sudah diperoleh 5 keuntungan, yaitu (1) increased motivation, (2) increased problem solving ability, (3) improved library research skill, (4) increased collaboration, dan (5) increased resource-management skillsi dengan pemaparan sebagai berikut: membuat rasa ingin tahu siswa bertambah setelah ditayangkan video yang menarik dan saat melakukan pengumpulan informasi (increased motivation and improve library research skill), sikap tanggung jawab dan peduli siswa menjadi lebih baik saat melakukan perancangan proyek, penyusunan jadwal, dan penyelesaian proyek secara berkelompok (increase collaboration, problem solving ability and increased resourcemanagement skill). Munculnya sikap santun dan menghargai dalam bertanya, berpendapat, dan menyampaikan hasil kegiatan. Siswa juga lebih percaya diri dalam menyampaikan hasil kegiatannya dengan presentasi dan pemajangan hasil karya, serta terbiasanya siswa menunjukkan sikap cinta lingkungan dengan menjaga kelas tetap bersih dan mengolah barang bekas menjadi sesuatu yang lebih berguna bagi siswa maupun orang lain. Susanto (2013:208) berpendapat, "pemerolehan pengetahuan dan proses pemahaman akan sangat terbantu, apabila siswa dapat sekaligus melakukan sesuatu yang terkait dengan keduanya, yaitu dengan mengerjakannya maka siswa akan menjadi lebih tahu dan paham", ini berarti pembelajaran berbasis proyek sangat sesuai diterapkan bagi siswa karena inti dari model pembelajaran ini adalah siswa mengerjakan apa yang dipelajarinya sehingga dapat meningkatkan hasil belajar kompetensi pengetahuan, kompetensi keterampilan, maupun kompetensi sikap siswa. Pada siklus II indikator keberhasilan peneplitian ini telah tercapai, maka tindakan dihentikan pada siklus II.

\section{Simpulan dan Saran}

Dari hasil penelitian dan pembahasan tersebut, maka dapat disimpulkan bahwa melalui model pembelajaran berbasis proyek berbantuan media audiovisual dapat meningkatkan hasil belajar IPA siswa. Hal ini ditunjukkan dengan data hasil belajar siswa meningkat 3\% pada siklus I dengan rata-rata nilai (M) 79 dan persentase rerata nilai (M\%) sebesar $79 \%$. Pada siklus II rata-rata nilai (M) meningkat menjadi 86 dengan persentase rerata nilai (M\%) sebesar $86 \%$ dan sudah masuk kategori tinggi pada skala PAP. Jadi dapat disimpulkan penerapan 
model pembelajaran berbasis proyek berbantuan media audiovisual dapat meningkatkan hasil belajar IPA siswa kelas V SDN 3 Banjar Jawa Singaraja semester II tahun Pelajaran 2017/2018.

Berdasarkan simpulan, dapat diberikan beberapa saran sebagai berikut: (1) bagi sekolah, pembelajaran berbasis proyek berbantuan media audio visual dapat dijadikan salah satu alternatif model pembelajaran inovatif yang sesuai untuk membelajarkan pembelajaran tematik dengan muatan materi IPA di sekolah dasar (SD). Penerapan model pembelajaran berbasis proyek berbantuan media audio visual sebagai upaya mendukung kurikulum 2013 dalam meningkatkan hasil belajar siswa berupa penyelarasan kompetensi sikap, pengetahuan dan keterampilan, (2) bagi guru umumnya agar selalu mencari inovasi baru dalam pelaksanaan pembelajaran sebagai pembaharuan guna mencapai kualitas pembelajaran yang lebih optimal, (3) bagi peneliti lain yang ingin mengadakan penelitian mengenai model pembelajaran berbasis proyek berbantuan media audio visual pada pembelajaran dengan muatan materi IPA maupun muatan materi pelajaran lain yang sesuai, agar memperhatikan hambatan - hambatan yang dialami pada penelitian ini sebagai bahan pertimbangan untuk perbaikan dan penyempurnaan pelaksanaan penelitian.

\section{Daftar Rujukan}

Arsyad, Azhar. 2014. Media Pembelajaran. Jakarta: RajaGrafindo Persada

Daryanto. 2014. Pendekatan Pembelajaran Saintifik Kurikulum 2013. Yogyakarta:Gava Media

Depdikbud.2014a. Lampiran I Peraturan Menteri Pendidikan dan Kebudayaan Republik Indonesia Nomor 57 Tahun 2014 Tentang Kurikulum 2013 Sekolah Dasar/Madrasah Ibtidaiyah

. 2014b. Lampiran I Peraturan Menteri Pendidikan dan Kebudayaan Republik Indonesia Nomor 103 Tahun 20014 Tentang Pembelajaran pada Pendidikan Dasar dan Pendidikan Menengah

. 2014c. Lampiran I Peraturan Menteri Pendidikan dan Kebudayaan Republik Indonesia

Nomor104 Tahun 2014 Tentang Penilaian Hasil Belajar oleh Pendidik pada Pendidikan Dasar dan Pendidikan Menengah

Dimyati dan Mudjiono. 2009. Belajar dan Pembelajaran. Jakarta: Rineka Cipta

Jihad, Asepdan Abdul Haris. 2012. Evaluasi Pembelajaran. Yogyakarta: Multi Pressindo

Kosasih, E. 2014.Strategi Belajar dan Pembelajaran implementasi Kurikulum 2013. Bandung: Yrama Widya

Sani, Abdullah. 2014. Pembelajaran Saintifik Untuk Implementasi Kurikulum 2013. Jakarta: Bumi Aksara

Sudjana, Nana. 2013. Penilaian Hasil Proses Belajar Mengajar.Bandung: Remaja Rosdakarya.

Susanto, Ahmad. 2014. Teori Belajar dan Pembelajaran di Sekolah Dasar.Jakarta : Kencana.

Taniredja, Tukiran, dkk. 2011. Penelitian Tindakan Kelas Untuk Pengembangan Profesi Guru. Bandung: Alfabeta

Wena, Made. 2014. Strategi Pembelajaran Inovatif Kontemporer. Jakarta: Bumi Aksara. 
Jurnal IImiah Pendidikan Profesi Guru Vol. 1 No. 1, April 2018

P-ISSN : 2621-5713, E-ISSN : 2621-5705

Wisudawati, Asih Widi dan Eka Sulistyowati. 2014. Metodologi Pembelajaran IPA. Jakarta: Bumi Aksara 